\title{
Correction to: Informal institutions, transaction risk, and firm productivity in Myanmar
}

\author{
Michael Danquah $\cdot$ Kunal Sen
}

Published online: 22 May 2021

(C) Springer Science+Business Media, LLC, part of Springer Nature 2021

\section{Correction to: Small Bus Econ} https://doi.org/10.1007/s11187-020-00441-w

The original version of this article was published with incorrect copyright name.

The corrected copyright is shown below.

CUNU-WIDER 2021.

The original article has been corrected.

Publisher's note Springer Nature remains neutral with regard to jurisdictional claims in published maps and institutional affiliations.

The online version of the original article can be found at https://doi.org/10.1007/s11187-020-00441-w

M. Danquah · K. Sen

UNU-WIDER, Helsinki, Finland

K. Sen $(\bowtie)$

Global Development Institute, University of Manchester,

Manchester, UK

e-mail: sen@wider.unu.edu 